\title{
Najnowsze wskazania Stolicy Apostolskiej odnośnie do życia konsekrowanego
}

Zagadnienie najnowszych wskazań Stolicy Apostolskiej dotyczących życia konsekrowanego jest niezwykle obszerne, wymagające szczegółowych badań, dlatego jedna publikacja z pewnością go nie wyczerpie. Temat ten wydaje się dość teoretyczny, a takie nie są lubiane. Z drugiej jednak strony, kwestie te są praktyczne, bo takie jest przecież życie konsekrowane, polegające na praktyce rad ewangelicznych, czyli na konkretnym realizowaniu czystości, ubóstwa i posłuszeństwa. Jednak trzeba wiedzieć, jak je realizować, w jaki sposób, by nie pobłądzić, by obrana droga nie była drogą prywatną, indywidualną, gdyż ma być realizowana w Kościele - czyli tak, jak Kościół to unormował w swoim prawodawstwie oraz jak to zostało unormowane w prawodawstwie poszczególnych instytutów życia konsekrowanego i stowarzyszeń życia apostolskiego.

W Kodeksie prawa kanonicznego czytamy: „Przełożeni każdego instytutu powinni upowszechniać znajomość tych dokumentów Stolicy Świętej, które dotyczą powierzonych im członków, jak również zatroszczyć się o to, by były przestrzegane" ". Nie jest to wymóg nowy, zapisany w obecnie obowiązującym prawie kodeksowym. Istniał on już

Codex Iuris Canonici auctoritate Joannis Pauli PP. II promulgatus. Kodeks prawa kanonicznego. Przekład polski zatwierdzony przez Konferencję Episkopatu, Poznań 1984 [dalej: KPK], kan. 592 \2. 
wcześniej, nawet w bardziej konkretnej formie. Kodeks prawa kanonicznego z 1917 roku bowiem wymagał, aby każdy przełożony szerzył między podwładnymi znajomość i wykonanie dekretów Stolicy Apostolskiej odnoszących się do zakonników ${ }^{2}$, na przełożonych miejscowych zaś nakładał obowiązek troski o to, by przynajmniej raz w roku, w ustalonych dniach, czytano oprócz własnych konstytucji również dekrety, które z polecenia Stolicy Apostolskiej powinny być czytane publicznie ${ }^{3}$. Warto także podkreślić, iż obecny zapis o poznawaniu dokumentów Stolicy Apostolskiej dotyczących życia konsekrowanego został zaczerpnięty z treści soborowej konstytucji dogmatycznej o Kościele Lumen gentium ${ }^{4}$ oraz z wytycznych dla wzajemnych stosunków między biskupami i zakonnikami Mutuae relationes Świętej Kongregacji Zakonów i Instytutów Świeckich i Kongregacji Biskupów ${ }^{5}$.

Skoro więc kościelny prawodawca wymaga, by upowszechniać znajomość dokumentów Stolicy Apostolskiej o życiu konsekrowanym i troszczyć się, aby były one przestrzegane, należy zapytać, o jakie konkretnie dokumenty chodzi. To jednak prowokuje do innego pytania, które trzeba zadać jako pierwsze. Co to znaczy ,najnowsze wskazania Stolicy Apostolskiej”, gdyż takie sformułowanie znalazło się w tytule tego opracowania? Chodzi oczywiście o ramy czasowe. Gdybyśmy mówili np. o najnowszej historii Polski, to z pewnością trzeba by wziąć pod uwage rok 1989, czyli początek przemian ustrojowych w dawnej PRL. W naszym temacie taką cezurę wydaje się wyznaczać II Sobór Watykański. Choć to czas odległy, bo minęło już pięćdziesiąt lat od jego zakończenia, to w życiu konsekrowanym oznacza on początek nowego etapu. Kościół na nowo bowiem starał się odczytać swoją misję we wspólczesnym świecie. Jeden z ważnych elementów tej renowacji i akomodacji stanowiło życie zakonne. Ono także musiało ulec znacznym przemianom, by nie rozminąć się ze współczesnością.

2 Por. Codex Iuris Canonici Pii X Pontificis Maximi iussu digestus Benedicti Papae XV auctoritate promulgatus, Typis Polyglottis Vaticanis 1943, can. $509 \$ 1$.

3 Codex Iuris Canonici Pii X Pontificis Maximi..., dz. cyt., can. $509 \$ 2$.

4 Zob. II Sobór Watykański, Konst. dogm. o Kościele Lumen gentium, w: II Sobór Watykański, Konstytucje - Dekrety - Deklaracje, Poznań 2002 [dalej: LG], nr 25.

5 Zob. Święta Kongregacja Zakonów i Instytutów Świeckich i Kongregacja Biskupów, Wytyczne dla wzajemnych stosunków między biskupami i zakonnikami Mutuae relationes, 14 maja 1978, w: Jan Paweł II, O życiu zakonnym. Przemówienia. Listy apostolskie. Instrukcje, wybór i oprac. E. Weron, A. Jaroch, Poznań-Warszawa 1984, nr 29, 33. 
W opracowaniu tym zwrócimy uwage na dokumenty, listy, przemówienia papieży i dokumenty dykasterii watykańskich w interesującym nas temacie, wydane od czasu Soboru, by na końcu zaakcentować te obszary życia konsekrowanego, którym poświęca się w nich najwięcej uwagi.

\section{Dokumenty II Soboru Watykańskiego}

Studiując dokumenty soborowe pod kątem treści związanej z życiem zakonnym, należy zwrócić uwagę na dwa. Pierwszym z nich jest konstytucja dogmatyczna o Kościele Lumen gentium, która tej tematyce poświęca rozdział szósty, zatytułowany „Zakonnicy”. Z perspektywy czasu możemy powiedzieć, że nie jest to najszczęsliwsza nazwa, gdyż sugeruje, że treść rozdziału odnosi się tylko do tych, którzy złożyli sluby zakonne. Co zatem z instytutami świeckimi, których członkowie także zobowiązują się do przestrzegania rad ewangelicznych i które należą do instytutów życia konsekrowanego? ${ }^{6}$. Dalej, co ze stowarzyszeniami życia apostolskiego, które choć wprost nie należą do instytutów życia konsekrowanego, to jednak do nich dochodzą, a są wśród nich i takie, których członkowie zobowiązują się do przestrzegania rad ewangelicznych?? To ważne pytania w kontekście adresatów i obowiązywalności dokumentów Stolicy Apostolskiej o życiu konsekrowanym.

Abstrahując jednak od tych zagadnień, należy krótko wspomnieć, że autorzy Lumen gentium zamieszczają w tym rozdziale wytyczne dotyczace interpretacji rad ewangelicznych, kierowania ich praktykowaniem oraz ustanawiania form życia na nich opartego, umiejscawiają stan zakonny w strukturze Kościoła i ukazują jego najważniejsze zadania, określają kompetencje kościelnej hierarchii w kwestii zatwierdzania zakonnych regul, zagadnienia egzempcji i słusznej autonomii instytutów zakonnych oraz znaczenie rad ewangelicznych w życiu osoby konsekrowanej. Za Jackiem Salijem można powiedzieć, że rozdział ten zawiera podstawowe założenia doktrynalne i praktyczne życia zakonnego ${ }^{8}$.

\footnotetext{
Zob. KPK, kan. 710.

Zob. KPK, kan. 731 \$S 1-2.

Por. J. Salij, Wprowadzenie do Dekretu o przystosowanej do wspótczesności odnowie żcia zakonnego „Perfectae caritatis”, w: II Sobór Watykański, Konstytucje-Dekrety-Deklaracje, dz. cyt., s. 261.
} 
Drugim dokumentem II Soboru Watykańskiego, tym razem już w całości poświęconym życiu według rad ewangelicznych, jest dekret o przystosowanej do współczesności odnowie życia zakonnego Perfectae caritatis ${ }^{9}$. Prezentuje on główne kierunki, jakby drogowskazy, według których ma postępować ta odnowa. Ma ona więc być ustawicznym powracaniem ,do źródeł wszelkiego życia chrześcijańskiego i pierwotnego ducha stanowiącego natchnienie dla instytutów"10, przy jednoczesnym przystosowywaniu go ,do zmienionych warunków naszej doby"11.

O ważności tego dekretu świadczy między innymi to, że stanowi on jedno z głównych źródeł obecnego prawa kodeksowego. Dokładnie w siedemdziesięciu miejscach Kodeksu prawa kanonicznego prawodawca odwołuje się do tego soborowego dokumentu ${ }^{12}$. Niektóre zapisy kanonów są wprost zaczerpnięte z jego treści ${ }^{13}$.

Wziąwszy do ręki konstytucje poszczególnych instytutów zakonnych, świeckich i stowarzyszeń życia apostolskiego, na pewno znaleźlibyśmy w nich również bardzo dużo odwołań do dekretu, co potwierdza jego znaczenie. Bez wattpienia jest on fundamentem wszelkich norm dotyczących życia konsekrowanego.

Mówiąc o dokumentach soborowych dotyczących życia zakonnego, konieczne wydaje się ponadto przynajmniej wspomnienie o przepisach wykonawczych do dekretu Perfectae caritatis, zawartych w liście apostolskim motu proprio papieża Pawła VI, zatytułowanym Ecclesiae

$9 \quad$ II Sobór Watykański, Dekret o przystosowanej do współczesności odnowie życia zakonnego Perfectae caritatis, w: II Sobór Watykański, Konstytucje - Dekrety - Deklaracje, dz. cyt., s. 264-275 [dalej: PC]. We wcześniejszym tlumaczeniu na język polski dokument ten nazwany został: „Dekret o przystosowanej odnowie życia zakonnego Perfectae caritatis”. Zob. II Sobór Watykański, Konstytucje - Dekrety - Deklaracje, dz. cyt., s. 264-275.

10 PC 2.

11 PC 2.

12 KPK, kan. $573 \int \S 1-2,574 \llbracket 2,575,577,578,582,584,587 \int S 3$ i 4, $588 \int S$ 1 i $3,590 \$ 1,598 \$ \$ 1-2,599,600,601,602,603 \$ 1,605,607 \$ \$ 1-3,616$

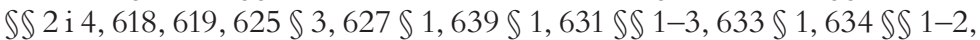
$635 \$ 2,640,642,651 \$ 3,652 \int \$ 2$ i 4, $659 \$ \$ 1-2,660 \$ \$ 1-2,661,662$, $663 \$ \$ 1-3,665 \$ 1,666,667 \$ 2-3,668 \$ 3,669 \$ 1,670,673,674,675 \$ \$$ $1-3,676,677 \$ 1,678 \int \$ 1-2,708,709,710,712,713 \rrbracket 2,714,716 \$ 2$,

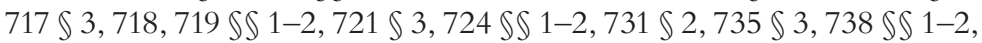
$740,741 § 2$.

10813 Zob. np. KPK, kan. 573 \& 1 (PC 1), kan. 578 (PC 2b), kan. 599 (PC 12). 
Sanctae $^{14}$. Choć list ten powstał po Soborze, w roku 1966, to jednak jest on integralnie związany z omawianym dokumentem soborowym i w tym miejscu można się na niego powołać. Ponieważ dekret Perfectae caritatis jest dekretem ogólnym, potrzebował uszczegółowienia w postaci norm wykonawczych. Składają się one z dwóch części. Pierwsza opisuje sposób popierania przystosowanej odnowy życia zakonnego, druga zaś przystosowanie i odnowę w nim niektórych rzeczy. Każdy więc instytut zakonny podejmujący odnowę w duchu wskazań II Soboru Watykańskiego obowiązkowo winien był uwzględnić $\mathrm{w}$ niej owe przepisy wykonawcze.

\section{Nauczanie papieża Pawła VI}

Pontyfikat Pawła VI (1964-1978) nie obfituje w wydane dokumenty, których autorem byłby właśnie ten następca św. Piotra. Z pewnością stało się tak, ponieważ był to okres rewizji prawa własnego poszczególnych instytutów, dla której podwaliny stanowił omawiany powyżej dekret Perefectae caritatis i normy wykonawcze Ecclesiae Sanctae. Nie było więc potrzeby wydawania innych dokumentów. Jedynym wyjątkiem jest adhortacja apostolska Evangelica testificatio z 1974 roku, zawierająca wskazania na temat odnowy życia zakonnego według nauki Soboru Watykańskiego ${ }^{15}$. Treściowo jest ona związana z dokumentami soborowymi i generalnie nie zawiera nowych elementów, ale „daje jednak nowe ich naświetlenie i jest wskazaniem nadającym kierunek dalszemu procesowi odnowy życia zakonnego"16. Zgodnie z tytułem - Ewangeliczne świadectwo - stara się ona ukazać różne wymiary życia zakonnego właśnie w perspektywie świadectwa. Termin ten jest w niej wielokrotnie używany ${ }^{17}$.

14 Paweł VI, List apost. motu proprio Ecclesiae Sanctae, przepisy wykonawcze do dekretu II Soboru Watykańskiego Perfectae caritatis, 6 sierpnia 1966, w: Posoborowe prawodawstwo kościelne, dokumenty prawno-liturgiczne, zebrał i przel. E. Sztafrowski, t. I, z. 1, Warszawa 1968, s. 78-96.

15 Paweł VI, Adh. apost. Evangelica testificatio, wskazania na temat odnowy życia zakonnego według nauki Soboru Watykańskiego II, 29 czerwca 1971 [dalej: ET], w: tenże, Charyzmat życia zakonnego. Przemówienia i dokumenty, wybór i oprac. A. Żuchowski, T. Sułowska, Poznań-Warszawa 1974, s. 232-259.

16 Przedmowa, w: Paweł VI, Charyzmat życia zakonnego. Przemówienia i dokumenty, dz. cyt., s. 12 .

17 Zob. ET 1, 3, 19, 22, 30, 31, 50, 52, 53, 55, 56. 
Trzeba jednak koniecznie powiedzieć, że to nie jedyny tekst Pawła VI dotyczący życia zakonnego. Jego troskę o ten rodzaj życia Bogu poświęconego widzimy także w bardzo licznych przemówieniach skierowanych do Unii Przełożonych Generalnych, międzynarodowych kongresów instytutów zakonnych, kapitul generalnych czy też wygłoszonych z różnych okolicznościowych okazji ${ }^{18}$. Ojciec święty porusza w nich między innymi zagadnienie istoty tego życia, miejsca zakonów w Kościele, rad ewangelicznych, wierności charyzmatowi, odnowy zakonnej.

\section{Nauczanie papieża Jana Pawła II}

Spuścizna Jana Pawła II w kwestii życia konsekrowanego stanowi ogromne bogactwo różnego rodzaju tekstów. Składają się na nią adhortacje apostolskie, listy, przemówienia, katechezy. Pośród adhortacji najpierw, ze względu na datę wydania, należy wymienić Redemptionis donum, traktującą o konsekracji zakonnej w świetle tajemnicy Odkupienia $^{19}$, a wydaną w jubileuszowym Roku Odkupienia (1983-1984).

Kolejną i szczególną adhortacją jest Vita consecrata, o życiu konsekrowanym i jego misji w Kościele i w świecie, z 1996 roku $^{20}$. Dokument ten jest owocem synodu biskupów, który odbył się w 1994 roku. To niemalże traktat o życiu konsekrowanym, choć nie naukowy, a bardziej duchowy, w stylu zachęty, a czasem napomnienia. Do momentu jej wydania nie ukazał się żaden dokument tak wyczerpująco i kompleksowo prezentujący życie według rad ewangelicznych, nie licząc Kodeksu prawa kanonicznego z 1983 roku²1, który

18 Zostały one zebrane, w liczbie 42, w książce: Paweł VI, Charyzmat życia zakonnego. Przemówienia i dokumenty, dz. cyt. Nie są to jednak wszystkie przemówienia tego papieża, a jedynie wybrane, wygłoszone od początku jego pontyfikatu do roku 1973. Według wydawców tej publikacji, choć nie zawiera ona wszystkich przemówień, przedstawia całoksztalt myśli ojca świętego na temat życia konsekrowanego oraz jego wielką troskę o rozwój i prawdziwą odnowę tego życia. Por. Paweł VI, Charyzmat życia zakonnego..., dz. cyt., Przedmowa, s. 11.

19 Jan Paweł II, Adh. apost. Redemptionis donum, o konsekracji zakonnej w świetle tajemnicy odkupienia, 25 marca 1984.

20 Jan Paweł II, Adh. apost. Vita consecrata, o życiu konsekrowanym i jego misji w Kościele i w świecie, 25 marca 1996.

21 Kodeks prawa kanonicznego z 1983 roku przepisy dotyczące życia konsekrowanego podaje w kan. 573-746. 
jednak ujmuje ten temat od strony czysto prawnej, nie zaś teologicznej, jak ta właśnie adhortacja. Dopiero zestawienie tych dokumentów razem daje w miarę pełny obraz życia konsekrowanego. Szeroki wachlarz zagadnień zawarty został w trzech podzielonych na mniejsze jednostki rozdziałach: „Confessio Trinitas. Chrystologiczno-tryniatrne źródła życia konsekrowanego”, ,,Signum fraternitas. Życie konsekrowane znakiem komunii w Kościele”, wreszcie „Servitium caritatis. Życie konsekrowane objawieniem Bożej miłości w świecie”. Choć od ogłoszenia adhortacji apostolskiej Vita consecrata minęło już dziewiętnaście lat, nie straciła ona na aktualności - zawarte w niej wskazania wciąż winny być realizowane w praktyce życia Bogu poświęconego przez profesję rad ewangelicznych.

Spoglądając na dorobek papieża Jana Pawła II dotyczący życia konsekrowanego, wymienić należy także jego listy. Pośród nich godny zauważenia jest list apostolski z 1988 roku skierowany do osób konsekrowanych z okazji Roku Maryjnego Ad omnes personas consecratas ${ }^{22}$. Głównym przesłaniem tego teologicznego, a nawet ascetycznego listu jest ukazanie Maryi podążającej za Chrystusem i wypełniającej wolę Ojca. To wzór dla osób konsekrowanych w realizacji ich powołania i posłannictwa w Kościele.

Innym listem apostolskim jest Los caminos del Evangelio z 1990 roku, który Jan Paweł II dedykował zakonnikom i zakonnicom Ameryki Łacińskiej na 500-lecie ewangelizacji Nowego Świata ${ }^{23}$. Choć ma on za adresatów osoby konsekrowane konkretnego regionu świata, to jednak są w nim elementy uniwersalne, właściwe dla wszystkich żyjących radami ewangelicznymi w instytutach czy stowarzyszeniach. Warto podkreślić, iż papież rysuje w nim cele stawiane przez teraźniejszość, a także wyzwania przyszłości.

Bardzo cenne wskazania na temat życia konsekrowanego znajdujemy w środowych katechezach papieża Polaka. Wygłaszal je podczas audiencji generalnych od 28 września 1994 roku do 29 marca 1995 roku. W sumie jest ich dziewiętnaście. Poruszał w nich wszystkie istotne zagadnienia tego życia, takie jak między innymi formy życia konsekrowanego i budzenie powołań do nich, poszczególne rady

22 Jan Paweł II, List apost. z okazji Roku Maryjnego Ad omnes personas consecratas, 22 maja 1988.

23 Jan Paweł II, List apost. Los caminos del Evangelio, do zakonników i zakonnic Ameryki Łacińskiej na 500-lecie ewangelizacji Nowego Świata, 29 czerwca 1990. 
ewangeliczne, życie wspólne, świadectwo życia osób konsekrowanych, praktyka modlitwy w życiu konsekrowanym ${ }^{24}$.

Wspomniany cykl przemówień do osób i o osobach konsekrowanych nie jest jedyny. W czasie długiego pontyfikatu Jana Pawła II (1978-2005) przemówień o tej tematyce było bardzo dużo ${ }^{25}$. Gdyby do nich dodać jeszcze te, które wygłosił podczas pielgrzymek do ojczyzny, byłby to zbiór naprawdę imponujący.

\section{Nauczanie papieży Benedykta XVI i Franciszka}

Papież Benedykt XVI w czasie swojego kilkuletniego pontyfikatu (2005-2013) nie wydał żadnego dokumentu dotyczącego życia konsekrowanego, co nie znaczy, że te zagadnienia były mu obce - wręcz przeciwnie. W jego spuściźnie jest wiele tekstów skierowanych do osób konsekrowanych i mówiących o konsekrowanych (listy, przesłania, przemówienia, homilie, katechezy...). W 2009 roku ukazała się w języku polskim publikacja ${ }^{26}$ zawierająca teksty tego papieża adresowane do osób konsekrowanych z lat 2005-2008; w ciągu niespełna czterech lat było ich w sumie trzydzieści sześć. A na Stolicy Piotrowej zasiadał on do 28 lutego 2013, zatem jest ich dużo więcej. Wśród nich są przemówienia skierowane bądź wprost do osób konsekrowanych, bądź do części lub całej społeczności kościelnej, w których dany passus poświęcony został interesującym nas tutaj osobom. W bogatym zbiorze Benedykta XVI znajdują się także listy i przemówienia, które kierował on do określonej rodziny zakonnej. Zawierają one cenne uwagi odnoszące się do wszystkich osób konsekrowanych.

To samo należy powiedzieć o ojcu świętym Franciszku. Dwuipółletnia posługa tego papieża obfituje w różne wypowiedzi i teksty

24 Te katechetyczne przemówienia zostały zebrane w publikacji: Życie konsekrowane w nauczaniu Jana Pawła II, red. Cz. Drążek, Kraków 1996, a zaczerpnięte z polskiego wydania „L'Osservatore Romano”: (1994) nr 12, (1995) nr 1, (1995) nr 2, (1995) nr 3, (1995) nr 5, (1995) nr 7.

25 Przemówienia z pierwszych lat pontyfikatu (listopad 1978 - maj 1983) zostaly zebrane w publikacji: Jan Paweł II, O życiu zakonnym. Przemówienia. Listy apostolskie. Instrukcje, dz. cyt. W sumie zamieszczonych tam zostało 59 przemówień.

11226 Zob. Benedykt XVI do osób konsekrowanych, red. M. Saj, Kraków 2009. 
dotyczące życia konsekrowanego. Koniecznie trzeba wspomnieć trwający obecnie Rok Życia Konsekrowanego. Z tej to okazji wydał on list apostolski ${ }^{27}$, w którym oprócz podanych głównych celów tego czasu w Kościele znajdujemy sporo odniesień do istoty i aktualności życia konsekrowanego.

\section{Dokumenty Kongregacji Instytutów Życia Konsekrowanego i Stowarzyszeń Życia Apostolskiego}

Adhortacje apostolskie, listy apostolskie, przemówienia, katechezy wymienionych papieży nie miały charakteru doktrynalnego; najczęściej były to teksty teologiczne, medytacyjne, co nie umniejsza ich wartości i znaczenia dla osób konsekrowanych. Dopiero jednak dokumenty Kongregacji Instytutów Życia Konsekrowanego i Stowarzyszeń Życia Apostolskiego wprost wskazują, co jest ważne w tym rodzaju życia Bogu poświęconego, co należy w nim zmienić, na co zwrócić szczególną uwagę.

Spoglądając na te dokumenty, jak zostało zaznaczone - od czasu II Soboru Watykańskiego, w pierwszym rzędzie należy wymienić instrukcję z 1969 roku Renovationis causam, poświęconą odnowie formacji zakonneje ${ }^{28}$. To temat wynikający z odnowy soborowej. Nawiązuje ona do dekretu Perfectae caritatis oraz przepisów wykonawczych zawartych w liście apostolskim Ecclesiae Sanctae. Oprócz podania zasad i kryteriów odnowy formacji, umieszczonych w części pierwszej, podaje jej szczególowe normy w części drugiej.

W tym samym roku Kongregacja ta wydała też inną instrukcję, Venite seorsum, o życiu kontemplacyjnym i klauzurze mniszek ${ }^{29}$. Składa się z ona z siedmiu części, bez podziału na mniejsze jednostki i bez tytułów. Jej zasadniczym tematem są motywy teologiczne życia kontemplacyjnego, w którym mocno zaakcentowano życie w samotności. Po nich, w siedemnastu oznaczonych już punktach, zamieszczono konkretne przepisy dotyczące papieskiej klauzury mniszek.

27 Franciszek, List apostolski do osób konsekrowanych z okazji Roku Życia Konsekrowanego, 24 listopada 2014.

28 Święta Kongregacja Zakonów i Instytutów Świeckich, Instrukcja Renovationis causam, o odnowie formacji zakonnej, 6 stycznia 1969.

29 Święta Kongregacja Zakonów i Instytutów Świeckich, Instrukcja Venite seorsum, o życiu kontemplacyjnym i klauzurze mniszek, 15 sierpnia 1969. 
Ważny, choć niewielki objętościowo, jest dekret dotyczący spowiedzi zakonników oraz niedopuszczenia z powodu choroby do złożenia ślubów-Dum canonicarum z 1970 roku $^{30}$. To jakby normatywna odpowiedź Kongregacji na pojawiające się kwestie związane $z$ tymi zagadnieniami.

W życiu każdego instytutu życia konsekrowanego zdarzały się i nadal zdarzają sytuacje, że któryś z jego członków go opuszcza. Ponieważ na początku może on mieć trudności z przejściem do innego sposobu życia i funkcjonowania w społeczności, potrzebuje pomocy od instytutu, do którego należał. Tej praktycznej kwestii zaradzić miał dekret o pomocy charytatywnej z 1974 roku $^{31}$.

Chociaż instytuty życia konsekrowanego należą do charyzmatycznej, nie hierarchicznej struktury Kościoła, to jednak żyją i posługują w konkretnym Kościele partykularnym, mającym swojego pasterza. W wielu kwestiach, także natury prawnej, są one uzależnione od ordynariusza miejsca. Z tego więc względu Święta Kongregacja Zakonów i Instytutów Świeckich oraz Kongregacja Biskupów wydały wytyczne dla wzajemnych stosunków między biskupami a zakonnikami - Mutuae relationes ${ }^{32}$. Ten obszerny dokument podzielony został na dwie części, pierwszą zatytułowaną „Niektóre elementy doktrynalne” i drugą: „Dyrektywy i normy”. W tym miejscu, niejako na marginesie, należy zaznaczyć, że obecnie trwają prace nad aktualizacją tych wytycznych, by uwzględnić w nich wymogi dzisiejszej doby.

Dimensio contemplativa ${ }^{33}$ to kolejny dokument skierowany do osób konsekrowanych. Powstał on w 1980 roku, a dotyczy kontemplacyjnego wymiaru życia zakonnego. Wyraźnie ukazuje, że kontemplacja w życiu szczególnie Bogu poświęconym nie jest zarezerwowana jedynie dla zakonów kontemplacyjnych, ale jest proprium każdej formy tego życia. Nawet pilna potrzeba apostolska nigdy nie może odsunąć na dalszy plan wymiaru duchowego życia zakonnego.

30 Święta Kongregacja Zakonów i Instytutów Świeckich, Dekret Dum canonicarum, dotyczący spowiedzi zakonników oraz niedopuszczenia z powodu choroby do złożenia slubów, 8 grudnia 1970.

31 Święta Kongregacja Zakonów i Instytutów Świeckich, Dekret De auxilio iis qui institutum deserunt praebendo, o pomocy charytatywnej dla osób opuszczających instytut zakonny, 25 stycznia 1974.

32 Święta Kongregacja Zakonów i Instytutów Świeckich i Kongregacja Biskupów, Mutuae relationes, wytyczne dla wzajemnych stosunków między biskupami i zakonnikami.

33 Święta Kongregacja Zakonów i Instytutów Świeckich, Dimensio contemplativa, kontemplacyjny wymiar życia zakonnego, 12 sierpnia 1980. 
Należy także wspomnieć o instrukcji Optiones evangelicae ${ }^{34}$ - zakony i promocja ludzka, także z 1980 roku. Dotyczy ona kwestii społecznych, gdyż ukazuje, jaki wkład mają wnieść zakony w aktualne wyzwania świata i społeczeństwa, uwzględniając w nich godność osoby ludzkiej.

Kolejny chronologicznie dokument to instrukcja Essential elements ${ }^{35}$, wydana w języku angielskim, nie zaś po lacinie, jak to ma miejsce zazwyczaj. To niezwykle ważny dokument, gdyż omawia istotne elementy życia konsekrowanego, szczególnie w odniesieniu do instytutów oddających się pracy apostolskiej. Oprócz wymiaru teologicznego zawiera on także część normatywną, czyli pełną syntezę przepisów kościelnych dotyczących tej formy życia.

Nie trzeba udowadniać, jak ważna w życiu konsekrowanym, na każdym jego etapie, jest formacja. Jak ją zorganizować i na co zwracać przy tym szczególną uwagę, mówi instrukcja Potissimum institutioni $^{36}$, promulgowana w 1990 roku. Wskazania w niej zawarte obejmują między innymi takie główne tematy, jak: konsekracja zakonna i formacja, wspólne aspekty wszystkich etapów formacji do życia zakonnego, etapy formacji zakonnej, formacja w instytutach całkowicie poświęconych kontemplacji, zwłaszcza mniszek, aktualne zagadnienia dotyczące formacji zakonników oraz zakonnicy - kandydaci do kapłaństwa i diakonatu.

Istotnym elementem życia konsekrowanego przeżywanego we wspólnocie jest życie braterskie. Temu zagadnieniu został poświęcony dokument Congregavit nos in unum Christi amor z 1994 roku $^{37}$. To bardzo teologiczny dokument ukazujący w tym właśnie, teologicznym, świetle więzi braterskie we wspólnocie zakonnej i wynikającej z tego misji.

W 1999 roku Kongregacja Instytutów Życia Konsekrowanego i Stowarzyszeń Życia Apostolskiego ponownie wróciła do zagadnienia życia kontemplacyjnego i klauzury mniszek, wydając instrukcję

34 Święta Kongregacja Zakonów i Instytutów Świeckich, Instrukcja Optiones evangelicae, zakony i promocja ludzka, 12 sierpnia 1980.

35 Święta Kongregacja Zakonów i Instytutów Świeckich, Essential elements, istotne elementy nauczania Kościoła na temat życia konsekrowanego w zastosowaniu do instytutów oddających się pracy apostolskiej, 31 maja 1983.

36 Kongregacja Instytutów Życia Konsekrowanego i Stowarzyszeń Życia Apostolskiego, Potissimum institutioni, wskazania dotyczące formacji w instytutach zakonnych, 2 lutego 1990.

37 Kongregacja Instytutów Życia Konsekrowanego i Stowarzyszeń Życia Apostolskiego, Życie braterskie we wspólnocie Congregavit nos in unum Christi amor, 2 lutego 1994. 
Verbi sponsa ${ }^{38}$. Jest ona jakby odpowiedzią na zalecenie Jana Pawła II zawarte w adhortacji apostolskiej Vita consecrata, a dotyczące ustalenia szczególnych norm odnoszących się do konkretnej dyscypliny klauzurowej. „Papież pragnął, by klauzura lepiej odpowiadała różnorodności instytutów kontemplacyjnych i tradycji klasztorów, tak aby kontemplacyjne mniszki klauzurowe, odrodzone przez Ducha Świętego i wierne swemu posłannictwu, kroczyly ku przyszłości z autentycznym zapałem i nową siłą" ${ }^{\prime \prime}$.

$\mathrm{Na}$ początku trzeciego tysiąclecia powstała instrukcja Ripartire da Cristo $^{40}$, o odnowionym zaangażowaniu życia konsekrowanego w nowej epoce. Jest ona owocem pytań i oczekiwań, jakie sformulowaly osoby konsekrowane w różnych częściach świata po wejściu w życie adhortacji apostolskiej Vita consecrata i po zaangażowaniu w Wielki Jubileusz 2000. Jak zaznaczają sami autorzy dokumentu, nie ma on charakteru doktrynalnego, ale pragnie pomóc w głębszym wejściu we wskazania duszpasterskie ojca świętego ${ }^{41}$. Stąd jego główne wątki koncentrują się wokół kwestii, które jednocześnie są tytułami poszczególnych części: życie konsekrowane obecnością miłości Chrystusa pośród ludzkości, odwaga w pokonywaniu prób i podejmowaniu wyzwań, życie duchowe na pierwszym miejscu oraz świadkowie miłości.

Kolejny dokument, z 2008 roku, porusza ważne zagadnienia związane z posługą władzy i posłuszeństwem w życiu konsekrowanym. To instrukcja Faciem tuam, Domine, requiram ${ }^{42}$. Motywem jej powstania są przemiany, jakie w ostatnich latach dokonały się w instytutach życia konsekrowanego, co spowodowało pogłębienie refleksji nad tą rzeczywistością, ale także zmianę sposobu odczuwania i przeżywania władzy i posłuszeństwa, zarówno w Kościele, jak i w społeczeństwie ${ }^{43}$.

38 Kongregacja Instytutów Życia Konsekrowanego i Stowarzyszeń Życia Apostolskiego, Instrukcja Verbi sponsa, o życiu kontemplacyjnym i klauzurze mniszek, 13 maja 1999.

39 Instrukcja Verbi sponsa, nr 2.

40 Kongregacja Instytutów Życia Konsekrowanego i Stowarzyszeń Życia Apostolskiego, Instrukcja Ripartire da Cristo, odnowione zaangażowanie życia konsekrowanego w trzecim tysiącleciu, 19 maja 2002.

41 Por. Instrukcja Ripartire da Cristo, $\mathrm{nr} 4$.

42 Kongregacja Instytutów Życia Konsekrowanego i Stowarzyszeń Życia Apostolskiego, Instrukcja Faciem tuam, Domine, requiram, posługa władzy i posłuszeństwo, 11 maja 2008.

43 Więcej na ten temat: Cz. Parzyszek, Postuszeństwo i postuga władzy w życiu konsekrowanym, Ząbki 2009. 
W 2014 roku Kongregacja Instytutów Życia Konsekrowanego i Stowarzyszeń Życia Apostolskiego wydała wytyczne dotyczące zarządzania dobrami materialnymi w instytutach i stowarzyszeniach ${ }^{44}$. Poruszane w nich kwestie skupiają się między innymi na zarządzaniu dobrami, wspólpracy z Kościołem lokalnym, z innymi instytutami i konsultantami, a także na formacji w tym zakresie.

Ze względu na Rok Życia Konsekrowanego, który trwał od 30 listopada 2014 do 2 lutego 2016, przywołać również należy dwie pozycje Kongregacji Instytutów Życia Konsekrowanego i Stowarzyszeń Życia Apostolskiego, wydane specjalnie na ten czas w Kościele. Pierwsza to Radujcie się. $Z$ nauczania papieża Franciszka $a^{45}$, druga Rozpoznawajcie. Do osób konsekrowanych podażajacych szlakiem znaków Bo$\dot{z} y c h^{46}$. Są to teksty czysto ascetyczne, ale bardzo wartościowe dla życia duchowego osób konsekrowanych. Warto przy ich lekturze zwrócić uwagę na dołączone na końcu refleksje papieża Franciszka, które można wprost odczytywać jako wskazania dla osób konsekrowanych.

\section{Wierność charyzmatowi instytutu}

Pośród istotnych elementów życia konsekrowanego, mocno akcentowanych przez Stolicę Apostolską, na początku należy wymienić charyzmat instytutów i troskę o jego zachowanie ${ }^{47}$. Zgodnie z normą kodeksową, wszyscy członkowie instytutów życia konsekrowanego „,powinni wiernie zachowywać mysl i zamierzenia założycieli, zatwierdzone przez kompetentną władzę kościelną, dotyczące natury, celu, ducha i charakteru instytutu, jak również zdrowych jego tradycji, co stanowi dziedzictwo

44 Kongregacja Instytutów Życia Konsekrowanego i Stowarzyszeń Życia Apostolskiego, List okólny: wytyczne dotyczące zarządzania dobrami w Instytutach Życia Konsekrowanego i Stowarzyszeniach Życia Apostolskiego, 2 sierpnia 2014.

45 Kongregacja Instytutów Życia Konsekrowanego i Stowarzyszeń Życia Apostolskiego, List okólny do osób konsekrowanych „Radujcie się”. Z nauczania papieża Franciszka, 2 lutego 2014.

46 Kongregacja Instytutów Życia Konsekrowanego i Stowarzyszeń Życia Apostolskiego, Rozpoznawajcie. Do osób konsekrowanych podążających szlakiem znaków Bożych, 8 września 2014.

47 Więcej na ten temat: M. Saj, Troska Kościoła o tożsamość instytutów życia konsekrowanego i stowarzyszeń życia apostolskiego, "Studia Redemptorystowskie” 13 (2015), s. 375-390. 
tegoż instytutu" ${ }^{48}$. Charyzmat to wszystkie elementy instytutu, które nadają mu indywidualną tożsamość, jakiej pragnął założyciel działający pod natchnieniem Ducha Świętego. To właśnie charyzmat odróżnia jeden instytut od innego. Kościół dba o to, by instytuty miały odrębny charakter i własne zadania, dlatego też tę odrębność należy zawsze ścisle zachowywać ${ }^{49}$. Myśl i zamierzenia założyciela dotyczące natury, celu, ducha i charakteru danego instytutu oraz jego zdrowych tradycji to elementy niezmienne, określone u początków instytutu czy stowarzyszenia, a aktualne po stu, dwustu i więcej latach jego istnienia.

Wspomniany już na początku tych rozważań dekret Perfectae caritatis wyraźnie nawołuje do powrotu do pierwotnego charyzmatu. Czytamy w nim: „Przystosowana do współczesności odnowa życia zakonnego obejmuje zarówno nieustanne powracanie do źródeł wszelkiego życia chrześcijańskiego i do pierwotnego ducha stanowiącego natchnienie dla instytutów, jak też ich przystosowanie do zmienionych warunków naszej doby" ${ }^{20}$. Ten ,„pierwotny duch” to nic innego jak laska, którą otrzymali założyciele instytutów, a która winna być nieustannie aktualizowana i przekładana na konkretne działanie. W odnowie tej nie chodzi więc o dosłowny powrót do pierwotnych warunków panujących w momencie zakładania danego instytutu, ale o odczytywanie ciagle na nowo jego charyzmatu, historii, pism i tradycji ${ }^{51}$.

Ojcowie soborowi stwierdzili, że Kościół „,swoim czujnym i pomocnym autorytetem wspiera instytuty [...], aby wzrastały i rozwijały się w duchu założycieli” ${ }^{52}$. Podają oni kilka zasad, według których winna być przeprowadzona odnowa. Jedna z nich brzmi: ,,Jest rzeczą dobrą dla samego Kościoła, by instytuty miały swój odrębny charakter i własne zadania. Dlatego należy uznawać i ścisłle zachowywać ducha i zamiary ich założycieli, a także zdrowe tradycje, bo wszystko to stanowi dziedziczną własność każdego instytutu"53.

\footnotetext{
KPK, kan. 578.

Por. PC $2 b$.

PC 2.

51 Por. K. Wójtowicz, Soborowa wizja odnowy i przystosowania w życiu konsekrowanym wedlug nauczania Jana Pawla II, w: „Biuletyn Konferencji Wyższych Przelożonych Żeńskich Zgromadzeń Zakonnych” XII (2005) nr 25, s. 31; J. Salij, Wprowadzenie do dekretu o przystosowanej do wspótczesności odnowie życia zakonnego, w: II Sobór Watykański, Konstytucje - Dekrety -Deklaracje, dz. cyt., s. 261.

52 Por. LG 45.
}

11853 PC 2b. 
Dekret Perfectae caritatis nakazuje zatem, by instytuty różniły się między sobą charakterem i zadaniami. Nadto Kościól chce, by instytuty i stowarzyszenia uznawały i zachowywały ducha i zamiary założycieli oraz swoje zdrowe tradycje, czyli by dbały o swoją tożsamość. W praktyce jednak zdarzało się, że skupiano się jedynie na części pierwszej tej zasady, a zapominano o drugiej, czyli o duchu i zamiarach założycieli. To doprowadziło do tego, że niektóre instytuty podążyły w zupełnie innym kierunku, niż pragnęli założyciele ${ }^{54}$.

Każdy następca św. Piotra, poświęcając wiele uwagi życiu konsekrowanemu, odnosi się bardzo często do kwestii charyzmatu, tożsamości instytutów. Dzisiaj już święty, papież Jan Paweł II podczas pielgrzymki do Gwatemali mówił do zakonników:

Wspominając założycieli Waszych instytutów, odczuwacie ten rodzaj „rodzinności”, która pozwala Wam utożsamić się z nimi i z Waszymi współbraćmi. Jest to poczucie, że charyzmat jest czymś żywym, żywotnym, ożywianym przez Ducha, czymś, co przybrało realny kształt poprzez doświadczenie formacji i życia zakonnego. Wy jesteście powiernikami tego ,doświadczenia Ducha”, jakim jest charyzmat założycieli, i zań odpowiadacie. Jesteście synami tych „mężów Ducha”, ich żywą obecnością w Kościele dzisiejszym ${ }^{55}$.

Podobne słowa wypowiedział podczas jednej z audiencji generalnych:

Historia uczy, że charyzmat życia konsekrowanego jest zawsze ,w ruchu", wykazując zdolność odkrywania i - rzec by można - ,wymyslania" - w duchu wierności wobec charyzmatu założyciela - nowych form, bardziej zgodnych z potrzebami i dążeniami danej epoki. Również wspólnoty istniejące już od wieków powinny przystosować się do tych potrzeb i dążeń, jeżeli nie chcą skazać się na zagładę ${ }^{56}$.

Jako zachętę, a nawet wezwanie można odczytywać pełne troski o zachowanie charyzmatu założyciela słowa Jana Pawła II zawarte

54 Por. J. Kałowski, Konstytucje jako zabezpieczenie celu i zadań instytutów życia konsekrowanego, „Prawo Kanoniczne” 36 (1993) nr 3-4, s. 16.

55 Jan Paweł II, Żywy depozyt charyzmatu założycieli. Przemówienie do zakonników w sanktuarium Serca Jezusowego, Gwatemala, 7 marca 1983.

56 Jan Paweł II, Życie konsekrowane w Kościele. Katecheza podczas audiencji generalnej, 8 lutego 1995, „L'Osservatore Romano” 12 (1994), s. 40. 
w liście do zakonników i zakonnic Ameryki Łacińskiej na 500-lecie ewangelizacji Nowego Świata, które to słowa, myślę, winna odnieść do siebie każda osoba konsekrowana. Ojciec święty pisał między innymi:

Wasi założyciele, tak jak to czynili w swoich czasach, również dzisiaj oddaliby na służbę Chrystusowi całą swoją energię apostolską, swój głęboki zmysł Kościoła, swoje twórcze inicjatywy duszpasterskie, swoje umiłowanie ubogich, będące źródłem tylu dzieł kościelnych. Wielkoduszność i poświęcenie, ożywiające waszych założycieli, powinny pobudzać również was, ich synów duchowych, którzy macie być kontynuatorami ich charyzmatów z tą samą siłą Ducha, który je wzbudził i które nieustannie się wzbogacają i przystosowują do świata, zachowując swój pierworodny charakter, dzięki czemu mogą służyć Kościołowi i ostatecznemu ustanowieniu Królestwa ${ }^{57}$.

Mówiąc o papieżu Polaku, wspomnieć jeszcze trzeba posynodalną adhortację apostolską Vita consecrata. Pisał w niej, że potrzebna jest wierność charyzmatowi założyciela i dziedzictwu instytutu, gdyż „,dzięki tej wierności wobec natchnienia założycieli i założycielek [...] można łatwiej odkryć i gorliwiej przeżywać zasadnicze elementy życia konsekrowanego" 58 . Z charyzmatu wynika konkretna misja instytutu, której formy winny być, gdy jest to konieczne, przystosowane do nowych sytuacji i rozmaitych potrzeb ${ }^{59}$.

Taką samą troskę o powrót do pierwotnego charyzmatu w życiu konsekrowanym widzimy u kolejnego następcy św. Piotra, Benedykta XVI. W przesłaniu do uczestników sesji plenarnej Kongregacji Instytutów Życia Konsekrowanego i Stowarzyszeń Życia Apostolskiego papież, podkreślając rolę założycieli i założycielek nowych form życia ewangelicznego, zaznaczył, że to oni przekazali swój charyzmat duchowym synom i córkom, i to dzięki temu we współczesnych czasach „w klasztorach i ośrodkach duchowości mnisi, osoby zakonne i konsekrowane stwarzają wiernym oazy kontemplacji i szkoły modlitwy, wychowania do wiary i duchowej opieki" "60. Jednocześnie ojciec święty pragnie uświadomić, iż to Duch Święty inspiruje założycieli i kształtuje

Jan Paweł II, Los caminos del Evangelio, nr 26.

VC 36.

Por. VC 37.

60 Benedykt XVI, Życie konsekrowane w świecie wspótczesnym. Przesłanie do uczestników sesji plenarnej Kongregacji Instytutów Życia Konsekrowanego 
instytuty z ich własnym dziedzictwem duchowym. Te charyzmaty są nadzwyczajnym skarbem, który tworzy ogromną duchową mądrość i który przyciągnie młodych ludzi do życia poświęconego Bogu w posłudze apostolskiej lub w życiu kontemplacyjnym. Benedykt XVI zachęca młodzież, by rozmawiała z osobami konsekrowanymi o charyzmatach i duchowości rodzin zakonnych, widząc w tym także możliwość odkrycia przez młodych własnego powołania do takiego rodzaju życia ${ }^{61}$. Z kolei instytutom życia konsekrowanego uzmysławia znaczenie powrotu do swych korzeni i prowadzenia życia zgodnego z duchem założycieli. Odkrywanie na nowo założycielskiego charyzmatu, który należy adaptować do dzisiejszych czasów, jest gwarancją nowego impulsu w życiu instytutów. Papież potwierdza, że dzięki temu wiele wspólnot ożywiło swoją realizację charyzmatu ${ }^{62}$.

Warto jeszcze zwrócić uwagę na wyzwania, jakie stoją przed osobami konsekrowanymi. Benedykt XVI, widząc „,zagubienie się Europy”, która „poszukuje swej duszy”, wskazuje na zadanie osób szczególnie Bogu poświęconych, by szukały nowych form życia charyzmatami swych założycieli, aby w ten sposób lepiej odpowiadać na najbardziej naglące wołanie współczesnego czasu, szczególnie wołanie ludzi młodych, będących nadzieją i przyszłością kontynentu. Papież widzi tutaj możliwość zainicjowania przez zakonników i zakonnice nowych dróg dla Europy ${ }^{63}$.

Przytoczonych wypowiedzi pasterzy Kościoła nie trzeba chyba komentować. Wyraźnie przebija z nich troska o charyzmat instytutów życia konsekrowanego i stowarzyszeń życia apostolskiego, o ich wierność pierwotnemu duchowi założyciela przy równoczesnym uwzględnianiu wymogów współczesności, miejsca i czasu.

i Stowarzyszeń Życia Apostolskiego, Castel Gandolfo, 27 września 2005, „L'Osservatore Romano” 11-12 (2005), s. 5.

${ }_{61}$ Por. Benedykt XVI, Wy jesteście uczniami Chrystusa w dzisiejszym świecie. Spotkanie z młodzieżą w Seminarium św. Józefa, Nowy Jork, 19 kwietnia 2008, „L'Osservatore Romano” 6 (2008), s. 25.

62 Por. Benedykt XVI, Kryzys i odrodzenie życia zakonnego. Do członków Rady ds. Kontaktów Kongregacji Instytutów Życia Konsekrowanego i Stowarzyszeń Życia Apostolskiego z Międzynarodowymi Uniami Przełożonych Generalnych, 18 lutego 2008, „L'Osservatore Romano” 4 (2008), s. 24.

63 Por. Benedykt XVI, Nasze życie duchowe wobec wyzwań, jakie przeżywa Europa. Przesłanie do zakonnic i zakonników Europy ogłoszone na zakończenie Zebrania Plenarnego Unii Konferencji Przełożonych Wyższych Europy, Fatima, 6-12 lutego 2006, Wiadomości KAI, 19 marca 2006, s. 27. 


\section{7. Życie duchowe}

Pierwszym i podstawowym prawem i oraz obowiązkiem każdej osoby konsekrowanej jest ,kontemplacja rzeczy Bożych oraz ustawiczne zjednoczenie z Bogiem w modlitwie" ${ }^{64}$. To istotny i nieodłączny element życia konsekrowanego. Gdy go zabraknie, każde inne działanie, choćby po ludzku rzecz biorąc, zakończone sukcesem, nie będzie miało wartości, nie wytrzyma próby czasu.

Życie duchowe nie sprowadza się zatem tylko do praktyk religijnych, ale zawsze nawiązuje do posług, które pełni osoba poświęcona Bogu, do posłannictwa, przez które osiąga doskonałośćc5. Można więc powiedzieć, iż jej duchowe życie jest ściśle związane z jej posługą, istnieje między nimi współzależnośćc6 ${ }^{6}$ Dojrzałe życie duchowe warunkuje dojrzałą duchowość zakonną i kapłańską oraz sposób jej realizacji. Życie duchowe i zakonne są ze sobą ściśle powiązane i trudno mówić o istnieniu jednego bez drugiego ${ }^{67}$.

Warto w tym miejscu odwołać się do stwierdzenia Jana Pawła II, który zauważył, że formacja duchowa powinna zajmować uprzywilejowane miejsce w życiu każdego człowieka ${ }^{68}$, a co dopiero osoby konsekrowanej. W adhortacji apostolskiej Vita consecrata pisał:

Rodziny życia konsekrowanego muszą zatem stawiać na pierwszym miejscu życie duchowe, tak aby każdy Instytut i każda wspólnota stanowiła prawdziwą szkołę ewangelicznej duchowości. Od tej pierwszoplanowej opcji, realizowanej na płaszczyźnie osobistej i wspólnotowej, zależy apostolska owocność Instytutu, ofiarność jego miłości do ubogich, a także jego zdolność przyciągania powołań spośród nowych pokoleń. Właśnie wysoki poziom duchowy życia konsekrowanego może wstrząsnąć świadomością ludzi naszych czasów, którzy

64 KPK, kan. $663 \$ 1$.

65 Por. Jan Paweł II, Adh. apost. Pastores dabo vobis, o formacji kapłanów we współczesnym świecie, 25 marca 1992, nr 45.

66 Por. Kongregacja Duchowieństwa, Dyrektorium o postudze i życiu kapłanów, 31 stycznia 1994, nr 14.

${ }^{67}$ Por. S. Urbański, Wspólnota zakonna miejscem życia braterskiego w mitości, „Życie Konsekrowane” 3 (1996), s. 62.

68 Por. Jan Paweł II, Duchowa wizja czlowieka. Przemówienie na spotkaniu z przedstawicielami różnych religii i kultur, Delhi, 2 lutego 1986, „L’Osservatore Romano" 1 (1986), s. 21. 
są spragnieni absolutnych wartości, i stać się w ten sposób porywającym świadectwem ${ }^{69}$.

W orędziu do uczestników zebrania plenarnego Świętej Kongregacji Zakonów i Instytutów Świeckich można było usłyszeć słowa:

Jest rzeczą jasną, że zakonnicy, aby mogli pozostać wierni swojemu poświęceniu się Bogu i aby mogli dawać temu poświęceniu świadectwo dostrzegalne przez innych, muszą doskonalić się w miłości, pozostając zawsze w modlitewnym dialogu z Bogiem. Aby zachować żywą świadomość wartości życia poświęconego Bogu, jest konieczna głęboka wiara, która z kolei musi być podtrzymywana i zasilana modlitwą. [...] Bez modlitwy życie zakonne traci sens i nie osiąga swego celu. [...] Dlatego też domy zakonne powinny być oazami modlitwy i skupienia, miejscami osobistego i wspólnotowego dialogu z Tym, który jest i powinien pozostać pierwszym i głównym rozmówcą w ich życiuำ.

Z kolei Benedykt XVI twierdzi, że to, czego Kościół oczekuje od życia konsekrowanego, dotyczy o wiele bardziej sposobu bycia niż działania ${ }^{71}$. Wierność przyjętym zobowiązaniom natomiast ,,jest możliwa dzięki stałej wierności w małych, ale niezbędnych sprawach codziennych: przede wszystkim wierność modlitwie i słuchaniu słowa Bożego; wierność w służbie ludziom naszych czasów, zgodnie z własnym charyzmatem; wierność nauczaniu Kościoła, poczynając od jego nauki na temat życia konsekrowanego; wierność sakramentom pojednania i Eucharystii, która nas podtrzymuje w trudnych sytuacjach życia codziennego" "72. Znaczące są słowa tego papieża wypowiedziane jeszcze przed objęciem Stolicy Piotrowej. Choć kierował je do prezbiterów, to jednak bezsprzecznie dotyczą one także osób konsekrowanych:

69 VC 93.

70 Jan Paweł II, Modlitwa podtrzymuje i zasila życie poświęcone Bogu, orędzie do uczestników zebrania plenarnego Świętej Kongregacji Zakonów i Instytutów Świeckich, 7 marca 1980, w: Jan Paweł II, O życiu zakonnym, dz. cyt., s. 81-82.

71 Por. Benedykt XVI, Posynodalna adh. apost. Sacramentum caritatis, o Eucharystii, źródle i szczycie życia i misji Kościoła, 22 lutego 2007, nr 81.

72 Benedykt XVI, Kościót i świat potrzebuja waszego świadectwa, do osób konsekrowanych diecezji rzymskiej, 10 grudnia 2005, „L'Osservatore Romano” 3 (2006), s. 36. 
Prezbiter musi być człowiekiem, który głęboko poznał Chrystusa, spotkał Go i nauczył się Go kochać. Musi on być człowiekiem modlitwy, człowiekiem prawdziwie duchowym. Kochać zaś to nie szukać samego siebie i nie dążyć do własnego wywyższenia, a uczyć się służyć, żyć dla Chrystusa i Jego owczarni. [...] Kto kocha, pragnie także poznać [...], a kto do głębi zna Chrystusa, pragnie dzielić się $\mathrm{z}$ innymi radością odkupienia, jakiego dostąpi ${ }^{73}$.

Życie duchowe osób konsekrowanych polega na dawaniu ,,prymatu Boga”. Poprzedni ojciec święty często używał tego pojęcia. Ten prymat ma czynić naszą epokę czasem łaski, ma wielkie znaczenie w obliczu doświadczania w niej wielkiej nieobecności Boga ${ }^{74}$. Młodych, którzy wybrali drogę kapłańską lub zakonną, papież pragnie swoim słowem umocnić, by mimo ciężaru zmagań, jakich wymaga niesienie świadectwa światu, codziennie chodzili w światłości Chrystusa - a będzie to możliwe dzięki wierności w modlitwie osobistej i liturgicznej, dzięki karmieniu się medytacją natchnionego słowa Bożego ${ }^{75}$.

Prymat Boga w naszym życiu czyni dzisiejsze czasy czasem łaski. Pokładanie ufności w Jezusie Chrystusie zakorzenia nas głęboko w Bogu i czyni możliwym zaufanie do siebie samych i do innych. Doświadczenie modlitwy i kontemplacji czyni z nas świadków, zdolnych do proponowania wiary w świecie, poszukującym sensu swego istnienia, często pozbawionym nadziei i niepewnym wobec przyszłości ${ }^{76}$.

Niezwykle konkretne w tym temacie są słowa papieża Franciszka. W jednej z homilii mówił:

73 J. Ratzinger, O naturze kaptaństwa, przemówienie wygłoszone w czasie VIII Synodu Biskupów w Rzymie, w 1990 „L’Osservatore Romano” 9 (1990), s. 4.

74 Por. Benedykt XVI, Nasze życie duchowe wobec wyzwań, jakie przeżywa Europa, dz. cyt., s. 27; Benedykt XVI, Kościót i świat potrzebuja waszego świadectwa, dz. cyt., s. 36.

75 Por. Benedykt XVI, Bądźcie znakiem odnowy dla ludu Bożego, Msza św. z biskupami, duchowieństwem, seminarzystami, nowicjuszami i nowicjuszkami w St. Mary's Cathedral, Sydney, 19 lipca 2008, „L'Osservatore Romano" 9 (2008), s. 24.

76 Benedykt XVI, Nasze życie duchowe wobec wyzwań, jakie przeżywa Europa, dz. cyt., s. 27. 
To On wybiera, On posyła, On powierza misję. Dlatego ważna jest modlitwa. Kościół, jak to wielokrotnie powtarzał Benedykt XVI, nie jest nasz, lecz Boga. A tymczasem jakże często my konsekrowani myślimy, że jest nasz, co? Robimy, co nam przyjdzie do głowy, a przecież to nie jest nasze, lecz Boga. Pole, które należy uprawiać, jest Jego. Tak więc misja jest przede wszystkim łaską. I jeśli apostoł jest owocem modlitwy, to w niej znajdzie światło i moc dla swojego działania. W gruncie rzeczy nasza misja nie jest owocna, a wręcz gaśnie w tym momencie, kiedy przerwaniu ulega połączenie ze źródłem, z Panem ${ }^{77}$.

\section{8. Świadectwo życia}

Tematyka świadectwa życia osób konsekrowanych pojawia się w różnym kontekście i przy różnych okazjach. Prawodawca kościelny w Kodeksie prawa kanonicznego z 1983 roku dobitnie stwierdza, iż ,apostolstwo wszystkich zakonników polega na świadectwie ich życia konsekrowanego, które winni ożywiać modlitwą i pokutą"78. Świadectwo zatem jest pierwszą i najważniejszą formą apostołowania właściwego osobom konsekrowanym. Od początku istnienia życia zakonnego tej właśnie formie oddania się Bogu przypisywano zadanie dawania świadectwa. Funkcja ta nie jest tylko jakąś ,,wypadkową" tego życia, ale należy do jego istoty. Z tego właśnie względu zagadnienie to znajduje miejsce i dowartościowanie w licznych kościelnych dokumentach i przemówieniach papieskich.

W posynodalnej adhortacji Jana Pawła II Vita consecrata czytamy, że osoby konsekrowane są ,,powołane, aby w każdej sytuacji dawać konkretne świadectwo swojej przynależności do Chrystusa"79. Ma ono głównie polegać na wierności obranej drodze, wierności ślubom zakonnym. Papież Polak podczas pielgrzymki do ojczyzny w 1997 roku mówił na Jasnej Górze:

77 Franciszek, Nie bójcie się Bożego pocieszenia ani porażek, dajcie się prowadzić Duchowi Świętemu, homilia w czasie Mszy św. z seminarzystami i adeptami życia zakonnego, Watykan, 7 lipca 2013.

78 KPK, kan. 673. O wadze świadectwa w życiu konsekrowanym świadczyć może także fakt, iż takiej normy nie znajdujemy w poprzednio obowiązującym Kodeksie prawa kanonicznego z 1917 roku.

79 VC 25. 
Postępujące zubożenie wartości ludzkich [...] sprawia, że szczere praktykowanie rad ewangelicznych nabiera szczególnego charakteru proroczego znaku. Rady ewangeliczne bowiem ukazują ludzkości [...] droge „duchowej terapii”, ponieważ odrzucają bałwochwalczy kult stworzenia i w pewnej mierze czynią widzialnym Boga żywego ${ }^{80}$.

Bardzo dobitnie brzmią również słowa Benedykta XVI:

Kościół potrzebuje waszego świadectwa, potrzebuje życia konsekrowanego, które z odwagą i w sposób twórczy podejmuje wyzwania naszych czasów. Wobec szerzenia się hedonizmu od was oczekuje się odważnego świadectwa czystości, będącej wyrazem serca znającego piękno i cenę Bożej miłości. Wobec dominującego dziś powszechnie pragnienia pieniądza waszym skromnym życiem i gotowością służenia najbardziej potrzebującym przypominacie, że Bóg jest prawdziwym bogactwem, które nie niszczeje. Wobec indywidualizmu i relatywizmu, prowadzących do tego, że człowiek staje się dla siebie jedyną normą, wasze braterskie życie zdolne poddać się kierownictwu, a więc gotowość do posłuszeństwa, potwierdza, że realizację samych siebie składacie w ręce Boga. Jakże nie wyrazić życzenia, żeby kultura rad ewangelicznych, będąca kulturą Błogosławieństw, mogła szerzyć się w Kościele, by podtrzymywać życie i świadectwo ludu chrześcijańskiego? ${ }^{81}$.

W kwestii wierności przyjętym w profesji zakonnej zobowiązaniom wypowiedział się, w charakterystycznym dla siebie stylu, także papież Franciszek:

Nie wiem, czy to prawda, ale powiedziano mi, że pragniecie oddać życie na zawsze Chrystusowi. Tak, teraz klaszczecie, świętujecie, ale kiedy skończy się miesiąc miodowy, co się stanie? Kiedyś jeden seminarzysta mówił mi, że chce służyć Bogu, ale tylko przez 10 lat. To jest niebezpieczne. Żyjemy pod presją kultury tymczasowości.

80 Jan Paweł II, Orędzie do osób konsekrowanych, przekazane przedstawicielom zakonów męskich i żeńskich obecnym na Jasnej Górze w czasie pielgrzymki do Ojczyzny, Częstochowa, 4 czerwca 1997, nr 4; por. VC 87. 
Wszystko jest na jakiś czas: małżeństwo, kapłaństwo, życie zakonne. To jest groźne. Musicie o tym pamiętać ${ }^{82}$.

Słysząc takie słowa następcy św. Piotra, możemy zdecydowanie powiedzieć, że brak wierności to brak świadectwa.

Trzy rady ewangeliczne: czystość, ubóstwo i posłuszeństwo. Wszystkie razem i każda z osobna to jakby odpowiedź dawana współczesnemu człowiekowi, zniewolonemu przez to, co oferuje świat, a co w ostateczności szczęścia nie daje. Każda osoba konsekrowana winna wziąć sobie głęboko do serca słowa Benedykta XVI:

Wy, drodzy kapłani, zakonnicy i zakonnice, wnosicie znaczący wkład: pośród całej zachłanności, całego egoizmu, który nie umie czekać, żądzy konsumpcji, wobec kultu indywidualizmu staramy się żyć bezinteresowną miłością do ludzi. Żyjemy nadzieją, która pozostawia Bogu zadanie urzeczywistnienia, ponieważ wierzymy, że On ją spełni. Co by się stało, gdyby w dziejach chrześcijaństwa nie istniały postaci będące drogowskazami dla ludu? Co by się stało z naszym światem, gdyby nie było kapłanów, gdyby nie było kobiet i mężczyzn w zakonach i wspólnotach życia konsekrowanego - osób, które swoim życiem dają świadectwo nadziei na pełniejsze zaspokojenie ludzkich pragnień oraz świadczą o miłości Bożej, przewyższającej wszelką ludzką miłość. Właśnie dzisiaj świat potrzebuje naszego świadectwa ${ }^{83}$.

Ponieważ dziś niepowstrzymanie szerzy się kult pieniądza, posiadania, konsumpcjonizmu, życie konsekrowane ma ukazywać inne wartości. Warto tu przytoczyć znamienne słowa Benedykta XVI wypowiedziane w Mariazell:

Kto pragnie iść za Chrystusem w sposób radykalny, musi wyrzec się dóbr materialnych. Musi jednak przeżywać to ubóstwo na wzór Chrystusa, stając się wewnętrznie wolnym dla bliźniego. Dla wszystkich chrześcijan, a zwłaszcza dla nas kapłanów, dla zakonników i zakonnic,

82 Franciszek, Wasza radość niech będzie świadectwem Ewangelii, przemówienie podczas spotkania z seminarzystami, nowicjuszami i nowicjuszkami, Watykan, 6 lipca 2013.

83 Benedykt XVI, Iść za Chrystusem znaczy przyswajać sobie Jego styl życia, nieszpory w sanktuarium dla duchowieństwa, zakonników i seminarzystów, Mariazell, 8 września 2007, „L'Osservatore Romano” 10-11 (2007), s. 23-24. 
dla pojedynczych osób oraz dla całych wspólnot, sprawa ubóstwa i ubogich powinna być zawsze na nowo przedmiotem poważnego rachunku sumienia. Uważam, że właśnie w naszej sytuacji, kiedy nie powodzi się nam źle, gdy nie jesteśmy ubodzy, powinniśmy zastanowić się w szczególności nad tym, jak szczerze przeżywać to powołanie. Chciałbym to polecić waszej - naszej - uwadze przy rachunku sumienia ${ }^{84}$.

Słowa papieża Franciszka w tej samej materii można by nazwać apelem skierowanym do osób konsekrowanych:

Obudźcie świat! Bądźcie świadkami odmiennego sposobu czynienia, działania, życia! [...] Ja oczekuję od Was tego świadectwa. Osoby konsekrowane muszą być mężczyznami i kobietami zdolnymi do obudzenia świata. [...] Musicie być naprawdę świadkami odmiennego sposobu czynienia i zachowania. [...] Tym, czego ja oczekuję, jest więc świadectwo. Pragnę od zakonników tego szczególnego świadectwa ${ }^{85}$.

\section{9. Życie braterskie we wspólnocie}

Jednym z najistotniejszych elementów życia zakonnego jest życie braterskie we wspólnocie, co poświadczają dokumenty soborowe, posoborowe, jak i prawodawstwo instytutów życia konsekrowanego. W Kodeksie prawa kanonicznego znajdujemy normę, iż

braterskie współżycie [...], poprzez które wszyscy członkowie jednoczą się w szczególną jakby rodzinę w Chrystusie, tak powinno być określone, ażeby stawało się dla wszystkich wzajemnym wsparciem w wypełnianiu własnego powołania. Przez braterską zaś wspólnotę zaszczepioną i ugruntowaną w miłości, członkowie winni stać się przykładem powszechnego pojednania w Chrystusie ${ }^{86}$.

Kwestia życia wspólnego ma w dzisiejszych czasach szczególne znaczenie, bowiem rozkład związków międzyludzkich, zwłaszcza

${ }^{84}$ Benedykt XVI, Iść za Chrystusem znaczy przyswajać sobie Jego styl życia, dz. cyt., s. 23.

85 Franciszek, Spotkanie z przełożonymi generalnymi zakonów męskich, Watykan, 29 listopada 2013.

$128 \quad 86 \quad$ KPK, kan. 602. 
w rodzinie, spowodował, że człowiek tęskni za wspólnotą. Ojcowie soborowi słusznie zauważają, że nie może on żyć samotnie, a swą pełnię może osiągnąć tylko we wspólnocie ${ }^{87}$. Ten zmysł wspólnotowy - zarówno kościelny, jak i zakonny - jest chyba jednym z momentów bardziej akcentowanych przez duchowość soborową i posoborową ${ }^{88}$.

Według Jana Pawła II, ,życie w braterskiej jedności [...] jest źródłem wielkiej siły apostolskiej" ${ }^{89}$. Kiedy indziej papież mówił:

Podstawowym warunkiem owocności życia zakonnego jest właściwa jakość braterskiego życia we wspólnocie. Co więcej, charakterystyczną cechą obecnej odnowy Kościoła i życia zakonnego jest poszukiwanie komunii i wspólnoty. Dlatego życie zakonne będzie miało tym głębszy sens, w im większym stopniu przyczyni się do budowy „,braterskiej wspólnoty, w której szuka się i miłuje przede wszystkim Boga" (por. kan. 619); straci natomiast rację bytu zawsze wtedy, gdy zagubiony zostanie w nim ten wymiar chrześcijańskiej miłości, który polega na budowaniu małej „Bożej rodziny” z tymi, którzy otrzymali to samo powołanie. [...] Jeśli jednak zaniedbuje się to publiczne świadectwo życia zakonnego na rzecz działalności apostolskiej lub osobistej samorealizacji, wspólnoty zakonne tracą swój potencjał ewangeliczny. [...] Nie tylko Kościól, ale całe społeczeństwo może czerpać korzyści z posługi braterskich wspólnot, które zgodnie ze swym powołaniem winny być punktami orientacyjnymi dla wszystkich ludzi zmagających się z problemami wypływającymi ze sprzeczności interesów, z różnic pokoleniowych, rasowych i kulturowych. Wspólnota zakonna może zatem być żywym świadectwem wobec świata spragnionego pokoju i dążącego do rozwiązania konfliktów. Wspólne życie zakonne nie jest bowiem abstrakcyjnym i nieosiągalnym ideałem, ale czymś bardzo konkretnym i widzialnym ${ }^{90}$.

87 Por. II Sobór Watykański, Konstytucja duszpasterska o Kościele w świecie współczesnym Gaudium et spes, nr 25; VC 51.

88 Por. J. Kałowski, Życie braterskie we wspólnocie, Warszawa 1999, s. 167-173.

89 Jan Paweł II, Żywy depozyt charyzmatu zatożycieli, przemówienie do zakonników w sanktuarium Serca Jezusowego, Gwatemala, 7 marca 1983, w: Jan Paweł II, O życiu zakonnym, dz. cyt., s. 247; por. PC 15.

90 Jan Paweł II, Wspólnota zakonna, przemówienie do uczestników Zgromadzenia plenarnego Kongregacji Instytutów Życia Konsekrowanego i Stowarzyszeń Życia Apostolskiego, 20 listopada 1992, „L'Osservatore Romano” 3 (1993), s. 34. 
$\mathrm{Na}$ ten istotny wymiar życia osób Bogu poświęconych zwracał również uwage papież Benedykt XVI. Wspólnotowy wymiar życia konsekrowanego ma być odpowiedzią na trudności, jakie przeżywa Europa. Podczas zebrania plenarnego Unii Konferencji Przełożonych Wyższych Europy w Fatimie padły słowa:

Życie wspólnotowe uczy nas ,,żyć razem” w sposób wymagający i jednocześnie bogaty w wartości ludzkie. Otwiera nas na zdolność do akceptowania inności i do uczenia się, z cierpliwością, dialogu, do spotkania z innym człowiekiem. Życie wspólnotowe stanowi zaproszenie do stałego przekraczania indywidualizmu i rozrywania kręgu lęków wobec innego, wobec obcokrajowca, wobec różnorodności [...]. Prowadzi nas do coraz większej solidarności między zgromadzeniami, kulturami, religiami [...]. Jest ono miejscem stałego rozeznawania pod kątem naszej misji ${ }^{91}$.

Dzięki życiu wspólnemu, będącemu częścią posłannictwa osób konsekrowanych, można pokazać, iż Ewangelia potrafı zmieniać także międzyludzkie relacje oraz że miłość nie jest utopią, ale fundamentem tworzenia bardziej braterskiego świata ${ }^{92}$.

Życie braterskie we wspólnocie, obok pomocy w realizacji własnego charyzmatu, ma być także świadectwem ewangelicznego życia. Mając to na uwadze i widząc wielki walor tegoż, Benedykt XVI zachęca - nie tylko osoby konsekrowanego, ale także kapłanów diecezjalnych - by razem tworzyli wspólnotę życia, by nie poddawali się pesymizmowi i zmęczeniu. Argumentuje, iż młodych ludzi nie będzie pociągać takie życie, kiedy będą widzieć kapłanów samotnych, smutnych i zmęczonych; nie przekonają się, że życie poświęcone Bogu może być również i ich przyszłością ${ }^{93}$. Bardzo mocne są słowa tego papieża wypowiedziane do osób konsekrowanych diecezji rzymskiej w 2005 roku: „Zasadniczą częścią waszego posłannictwa jest życie wspólnotowe. Dokładając starań, aby wspólnoty żyły duchem braterstwa, pokazujecie, że dzięki Ewangelii również ludzkie relacje mogą

Benedykt XVI, Nasze życie duchowe wobec wyzwań, jakie przeżywa Europa, dz. cyt. Por. Benedykt XVI, Kościót i świat potrzebują waszego świadectwa, dz. cyt., s. 27.

3 Por. Benedykt XVI, Spotkanie z duchowieństwem diecezji Aosta, Introd, 25 lipca 2005, „L'Osservatore Romano” 10 (2005), s. 37; Benedykt XVI, Życie konsekrowane w świecie wspólczesnym, dz. cyt., s. 36. 
się zmieniać, że miłość nie jest utopią, a wręcz jest sekretem budowania świata bardziej braterskiego" 94 .

Koniecznie trzeba jeszcze odwołać się do papieża Franciszka:

Jezus nie chce działać samodzielnie. Przyszedl, aby przynieść światu miłość Boga, i pragnie szerzyć ją poprzez komunię i braterstwo. Dlatego formuje wspólnotę uczniów, która jest wspólnotą misyjną. Natychmiast przygotowuje ich do misji, aby poszli. Ale uwaga: to działanie nie ma celu towarzyskiego spotkania, spędzania czasu razem. Nie, celem jest głoszenie Królestwa Bożego ${ }^{95}$.

Słowa te ukazują cel życia wspólnego, głoszenie Jezusa razem, we wspólnocie.

\section{Zakończenie}

Zaprezentowane wskazania Stolicy Apostolskiej dotyczące życia konsekrowanego to tylko mały wycinek z ogromnego bogactwa zagadnień aktualnych w życiu konsekrowanym. Prezentowane wymiary nie są w nim jednak nowością. Istniały zawsze, były ważne zawsze. Ale skoro Kościół obecnie bardzo je akcentuje, to znaczy, że widzi ich szczególną potrzebę właśnie dzisiaj. Omówione wyżej zostały cztery wymiary: wierność charyzmatowi instytutu, troska o życie duchowe, świadectwo życia osoby konsekrowanej oraz życie braterskie we wspólnocie. Są także inne, niewspomniane tutaj, wśród których należałoby wymienić choćby troskę o powołania czy relacje z pasterzami.

Sekretarz Kongregacji Instytutów Życia Konsekrowanego i Stowarzyszeń Życia Apostolskiego ks. abp José Rodríguez Carballo w swojej homilii podczas pierwszego światowego spotkania młodych osób konsekrowanych, odbywającego się w Rzymie w dniach 15-20 września 2015 roku, przekazał trzy hasła, które mogą pomóc osobom konsekrowanym na drodze twórczej wierności. Oto one: „Odwagi, bądźcie dzielni! Wytrwajcie i bądźcie wierni! Przynoście

94 Benedykt XVI, Kościót i świat potrzebuja waszego świadectwa, dz. cyt., s. 36.

95 Franciszek, Zachęta do poszukiwania misyjnego ducha i do lektury encykliki „Lumen fidei”, modlitwa maryjna z papieżem, Watykan, 7 lipca 2013. 
owoce, przebudźcie świat!"’96. Do nich dołączyłbym trzy programowe wezwania papieża Franciszka podarowane osobom konsekrowanym na Rok Życia Konsekrowanego: „Bądźcie radośni! Bądźcie odważni! Bądźcie kobietami i mężczyznami komunii!"’’7. Sądzę, że najnowsze wskazania Stolicy Apostolskiej dotyczące życia konsekrowanego można by streścić właśnie w tych sześciu słowach-hasłach: Odwagi, bądźcie dzielni! Wytrwajcie i bądźcie wierni! Przynoście owoce, przebudźcie świat! Bądźcie radośni! Bądźcie odważni! Bądźcie kobietami i mężczyznami komunii! To zadania dla wszystkich osób konsekrowanych, na dzisiaj i na jutro.

Marek Saj CSSR, Najnowsze wskazania Stolicy Apostolskiej odnośnie do życia konsekrowanego, [w:] Życie konsekrowane znakiem wiarygodności Kościoła, red. ks. Andrzej Dudek, ks. Robert Kantor, Kraków 2016, s. 105-132 (Lumen Gentium, 2).

DOI: http://dx.doi.org/10.15633/9788374385725.08

96 J. R. Carballo, Homilia podczas inauguracji światowego spotkania mtodych konsekrowanych, Watykan, 15 września 2015, www.redemptor.pl/watykan-czuwanie-mlodych-konsekrowanych-teksty-i-wideo/ (dostęp 20.09.2015).

97 Franciszek, List apostolski z okazji roku życia konsekrowanego Świadkowie radości, Watykan, 21 listopada 2014. 